\title{
Effect of supplemental potassium application on growth and yield of potato cultivars
}

Saqib Farooq ${ }^{1}$, Gohar Ayub ${ }^{1}$, Murad Ali $^{*}$, Ahmad Naeem ${ }^{1}$, Rabia Riaz $^{1}$, Mohammad Wasiullah Khan ${ }^{1}$, Muhammad Afzaal ${ }^{2}$, Rafi Ullah ${ }^{1}$, Kamran Rauf $^{1}$, Syed Qaiser Ali Shah ${ }^{1}$ and Imtiaz Khan ${ }^{1}$

1. Department of Horticulture, The University of Agriculture, Peshawar-25130-Pakistan

2. Department of Entomology, The University of Agriculture, Peshawar-25130-Pakistan

*Corresponding author's email: muradali75@aup.edu.pk

Citation

Saqib Farooq, Gohar Ayub, Murad Ali, Ahmad Naeem, Rabia Riaz, Mohammad Wasiullah Khan, Muhammad Afzaal, Rafi Ullah, Kamran Rauf, Syed Qaiser Ali Shah and Imtiaz Khan. Effect of supplemental potassium application on growth and yield of potato cultivars. Pure and Applied Biology. Vol. 8, Issue 2, pp 1554-1563. http://dx.doi.org/10.19045/bspab.2019.80096

\begin{tabular}{llll}
\hline \hline Received: 11/01/2019 & Revised: 05/05/2019 & Accepted: 15/05/2019 & Online First: 21/05/2019 \\
\hline
\end{tabular}

\section{Abstract}

A trail was carried out to evaluate the effect of supplemental potassium application on growth and yield of potato cultivars at Horticulture Farm, The University of Agriculture Peshawar during winter season, 2014. The experiment was laid out on Randomized Complete Block Design, with split plot arrangement, using three replications. Potassium was kept in main plot while potato cultivars were kept in subplot. Four levels of supplemental potassium $\left(0,50,75,100 \mathrm{~kg} \mathrm{ha}^{-1}\right)$ were allotted to main plots, whereas sub plot factor consisted of potato cultivars (Rocko, Kuroda and Asterix). The supplemental potassium levels significantly influenced the growth and yield of potato cultivars. The maximum values for growth variables; plant height $(45.82 \mathrm{~cm})$ and survival percentage $\left(89.56 \%\right.$ ) and yield variables; number of small tubers plant ${ }^{-1}(4.56)$, number of medium tubers plant ${ }^{-1}(4.11)$, number of large tubers plant ${ }^{-1}(4.56)$, tuber weight plant ${ }^{-1}$ (463.67), yield (21.65 tons ha ${ }^{-1}$ ) were found in plot treated with supplemental potassium applied @ $75 \mathrm{~kg} \mathrm{ha}^{-1}$. Among cultivars, the maximum values for growth variables; plant height $(45.33 \mathrm{~cm})$ and survival percentage $(85.30 \%)$ and yield variables; number of small tubers plant ${ }^{-1}(3.92)$, number of medium tubers plant ${ }^{-1}$ (3.33), number of large tubers plant ${ }^{-1}$ (3.83), tuber weight plant ${ }^{-1}$ (451.17), yield (21.15 tons $\mathrm{ha}^{-1}$ ) were found in cultivar Kuroda. Interaction between supplemental potassium levels and potato cultivars was found non-significant. Supplemental potassium should be applied @ of $75 \mathrm{~kg} \mathrm{ha}^{-1}$ to potato crop. Among tested cultivars, the cultivar Kuroda showed better growth and yield under the agro-climatic region of Peshawar.

Keywords: Solanum tuberosum L; Supplemental Potassium; Growth; Yield and Quality

\section{Introduction}

Potato (Solanum tuberosum L.) belongs to family Solanaceace, is herbaceous plant. It was introduced into Europe in the $16^{\text {th }}$ century by the Spanish explorers, and now it is cultivated throughout the world including the Indo-Pakistan subcontinents [1]. Potato is a cross pollinated plant and also a large 
amount of self-fertilization is done. Potato plant produces small green fruits resembling to green cherry or small green tomatoes. Each fruit have up to 300 numbers of seeds. Potato seed contain solanine (a toxic alkaloid) so it is not suitable for utilization. Potatoes are generally cultivated from small tubers (seed potato) and from true potato seeds (TPS) [2]. Potato is the fourth ranked important crop worldwide in production and occupies sixth position in yielding averaging 15.3 tons ha ${ }^{1}[3]$. In Pakistan, the area under potato cultivation is 0.174 million hectares with 3.80 million tons of total production and in Khyber Pakhtunkhwa (KP), potato was cultivated on 0.091 million hectares with yield of 0.126 million tons and the average yield is 13.75 tons ha $^{-1}$ during year 2012-2013 [4]. On the basis of fresh matter, potato is third highest yielding crop after sugar cane and sugar beet. It is rich sources of energy because it contains a large amount of carbohydrates. It also contain sufficient amount of Vitamin B, C and starch [5]. Potato is well known for containing high amount of starch, having excellent quality. Fresh potato tubers mainly consist of $1700 \mathrm{mg}$ carbohydrates and $200 \mathrm{ml}$ of protein per 100 gm. It also consist of some amount of fibers, calcium, vitamins $\mathrm{A}$ and $\mathrm{C}$ and small amount of riboflavin, ascorbic acid, nicotinamid and very low amount of fats [6]. Potato are used alone and mixed with meat, fish, chicken and vegetables. Potato chips are prepared and sold commercially. It is rich in carbohydrates, starch, protein, minerals and fair amount of vitamins, mostly vitamin $\mathrm{C}$ [1]. Potato crops mature in less time and give high yield but it takes a large amount of nutrients from soil. So potato crop should be fed with high and balance amount of essential nutrients for high and qualitative return. The soil must be nourished with high amount of nutrient for the better support and growth of crop to obtain the required yield [7]. The vital nutrients which are required to be apply for the good plant growth and development are sixteen. Among some of those essential nutrients are occurred naturally in soil, water and air, which are Carbon, Hydrogen and Oxygen, while other nutrients must be applied to obtain the desirable yield [8]. Potassium $(\mathrm{K})$ is one of the required essential nutrients that are needed for plant life to obtain better growth and development and yield. Its contributions is vital in enzymes activation and synthesis, photosynthesis, starch synthesis and sugar degradation [9]. Potassium (K) plays an outstanding role in plant photosynthesis, which results in high energy production, stomata control and transfer of nutrient in plant body, water uptake and helps in synthesis of different enzymes [10]. The use of required elements is very important for the proper and sustainable crop return. The amendment of phosphorus and nitrogen fertilizers are commonly used while the potassium is always neglected because of the usual accord that there is sufficient amount of potassium in our soil irrigated with canal water, regardless of crop requirements and continuous cropping, as a result the potassium is draining very quickly in Pakistan [11]. Potassium helps plant by providing resistance to environmental stress such as drought, winter hardiness and tolerance to diseases, insect pests and frost damage [12]. Thus, the crop suffering from potassium deficiency causes serious reduction in crop yield and become susceptible to diseases and pests, damage by frost and has reduced return and quality [13]. Evidence indicates that biotic stress can cause significant losses in yield of rice, wheat, maize, and potato with $31.2 \%, 28.2 \%$, $37.4 \%$ and $40.3 \%$ respectively. While the abiotic stresses cause more losses in crop yield of maize, wheat and potato with $65.8 \%$, $82.1 \%$ and $54.1 \%$ respectively. Potassium significantly control the losses caused by both biotic and abiotic stresses among all other essential elements [14].The use of 
potassium is generally neglected in Khyber Pakhtunkhwa (KP), Pakistan. So due to continuous cropping, the level of potassium is regularly degrading. Potato crop requires a balanced amount of fertilizer for proper yield. Potato yield can be greatly enhanced by potassium application because yield of 25 tons $\mathrm{ha}^{-1}$ depletes $225 \mathrm{~kg}$ of potassium from the soil [1]. Potassium contribution is outstanding in maintaining the plant life, growth and vigor. Potato crop sometime considered as the indicator crop for potassium availability in soil because it require high amount of $\mathrm{K}$ during its vegetative growth and tuber formation [15]. Global climate change is already affecting agricultural production. Major adaptation will involve planting time and cultivar selection depending on tolerance to different environmental stresses and geographical condition of specific area. Higher potato yield can be obtained by proper sowing time, balance fertilizer application and proper spacing. Late sowing of potato is more susceptible to frost damage thus lowering the yield. Due to global warming, the climate change occurs regularly which have high impact on crop growth and yield, so proper variety selection for a specific climate is important. In 2003 potato yield potential was declined at worldwide from $18 \%$ to $32 \%$ [16]. In the present research studies, less attention has been given to potassium fertilizers and selection of suitable variety for the increased yield and qualitative production. The present research work was designed to evaluate the proper supplemental potassium requirements and suitable potato cultivar required for obtaining increased and qualitative yield of potato crop.

\section{Materials and methods}

\section{Site Description}

An experiment "Effect of supplemental potassium application on growth and yield of potato cultivars" was carried out during October, 2014 at the Horticulture Research Farm, The University of Agriculture Peshawar, to investigate the optimum level of supplemental potassium application for the improved growth, yield and tuber quality of potato cultivars. Four levels of supplemental potassium were applied to three cultivars of potato through soil application after 40 days of sowing as the tuber formation starts.

\section{Experimental design}

The experiment was laid out in Randomize Complete Block Design (RCBD) with splitplot arrangement. Total treatments were twelve having three replications. Each replication was having 12 treatments and total treatments were 36 . The area of each experimental plot was $2.1 \mathrm{~m} 2$. The total experimental area was $75.6 \mathrm{~m} 2$. The cultural practices were performed on the basis of crop requirements.

\section{Soil analysis}

Soil Analysis was done by taking soil samples randomly before fertilization from the experimental plot area, with help of auger up to $30 \mathrm{~cm}$ depth for the proper soil analysis. All the samples were enveloped, tagged and assessed in the Soil Science Lab, Department of Soil \& Environmental Science at The University of Agriculture Peshawar for chemical properties and amount of nutrient available in soil. Soil composition in $\mathrm{mg} \mathrm{kg}$ ${ }^{1}$ is shown in table 1 .

Table 1. Soil analysis

\begin{tabular}{|c|c|c|c|c|c|c|}
\hline $\begin{array}{c}\text { Depth } \\
(\mathbf{c m})\end{array}$ & O.M \% & Nitrogen & Phosphorus & Potassium & pH & EC \\
\hline $0-30 \mathrm{~cm}$ & $0.42 \%$ & $0.81 \%$ & $\begin{array}{c}0.44 \mathrm{mg} \mathrm{kg}^{-} \\
1\end{array}$ & $57.1 \mathrm{mg} \mathrm{kg}^{-1}$ & 7.64 & $0.90 \mathrm{dsm}^{-1}$ \\
\hline
\end{tabular}




\section{Fertilizer application}

Field was fertilized with NPK @ 100-80-100 $\mathrm{kg} \mathrm{ha}^{-1}$, during field preparation, and half of the nitrogen was applied after one month of potato tuber sprouting.

\section{Crop Harvesting}

The crop was harvested at full maturity when the lower leaves become yellow.

\section{Data recording}

At physiological maturity, five plants were selected at random and their height was measured with the help of measuring tape from the tip to the start of plant crown and the average was computed. Number of small size (<25 gram) tubers, were collected from randomly selected five sample plants in all the treatments after harvesting and there average was determined. Numbers of medium size (25-75 gram) tubers were collected from randomly selected five sample plants in all the treatments after harvesting and there average was determined. Number of large size (>75 gram) tubers was selected from five plants randomly selected from each treatment in each replication after harvesting and there average was calculated. The tubers of randomly selected five plants were weighted and averaged at the time of harvest. Data was recorded by counting the total plants survived out of the total number of plants sprouted in each sub plot. The survival percentage was determined by the given formula:

Survival percentage $=$ Total number of plant survived / Total no of plants sprouted x100 Yield per hectare was calculated by means of the following formula:

Yield in tons per hectare $=$ Plot yield $(\mathrm{kg}) /$ Plot Area $\left(\mathrm{m}^{2}\right) \times 10000 \mathrm{~m}^{2}$

\section{Statistical procedure}

The data regarding with different variables were allotted to the statistical variance of analysis to observe the variation between different treatments and also to know the effect of interaction on onion crop. MSTATC (Michigan State University, USA) and
Statistical analysis software was used for ANOVA and LSD values [17].

\section{Results and discussion}

\section{Plant height (cm)}

Plant height was considerably affected by supplemental potassium (K) levels and potato cultivars, while its interaction was nonsignificantly affected (Table 3). Plots treated with supplemental potassium applied at the rate of $75 \mathrm{~kg} \mathrm{ha}^{-1}$ produced highest plant height $(45.82 \mathrm{~cm})$, followed by $(44.42 \mathrm{~cm})$ at $100 \mathrm{~kg} \mathrm{ha}^{-1}$ of supplemental potassium. The smallest $(39.91 \mathrm{~cm})$ plant height was obtained at control.

In case of cultivars, the highest plant height $(45.33 \mathrm{~cm})$ was obtained in cultivar Kuroda, followed by $(43.06 \mathrm{~cm})$ plant height in cultivar Rocko and the lowest plant height $(40.97 \mathrm{~cm})$ was obtained in cultivar Asterix. Potassium application enhance assimilate flow, increase photosynthesis and provide resistance against different environmental stresses like frost, drought, pests and heat etc, due to which plant growth was enhanced resulting in increased plant height. These findings are analogous with $[18,19]$ who reported that application of potassium significantly increase the plant height in potato crop. [20] also disclosed that the highest plant height is obtained when $160 \mathrm{~kg}$ $\mathrm{K} \mathrm{ha}{ }^{-1}$ is applied. [21], reported that potassium has antagonistic effect on other nutrients specially magnesium and calcium which might cause decrease in plant height when applied above optimum level.

The results showed that plant height significantly varies among potato cultivars which are in agreement with [22], who reported that potassium efficiency ratio is different among genotypes of potato and also the cultivars might be genetically different and respond different to abiotic conditions. These finding are also in line with the results of [23] who disclosed that productivity of sweet potato varieties were simulated by different potassium levels and the highest 
significant response was found at potassium applied at the rate of $160 \mathrm{~kg} \mathrm{ha}^{-1}$.

Table 2. Treatments of the experiment

\begin{tabular}{|c|c|c|}
\hline \multicolumn{4}{|c|}{ Factor A (Potassium levels) (kg ha-1) } \\
\hline K0 & \multicolumn{2}{c|}{ Control } \\
\hline K1 & 50 \\
\hline K2 & & 75 \\
\hline K3 & & 100 \\
\hline \multicolumn{5}{|c|}{ Factor B (potato cultivars) } \\
\hline Sub plot & C3 \\
\hline C1 & C2 & Asterix \\
\hline Rocko & Kuroda & .
\end{tabular}

Small healthy, equal size tubers were selected and sown on $10^{\text {th }}$ October, 2014. Sulphate of potash (SOP) was used as a potassium source.

Table 3. Effect of supplemental potassium application on plant height $(\mathrm{cm})$, Number of small tubers plant-1, Number of medium tubers plant-1, Number of large tubers plant-1, Tuber weight plant-1(gm), Survival percentage and Yield (tons ha-1) of potato

\begin{tabular}{|c|c|c|c|c|c|c|c|}
\hline $\begin{array}{c}\text { Supplementa } \\
\text { I Potassium } \\
\text { Levels (kg } \\
\left.\text { ha }^{-1}\right)\end{array}$ & $\begin{array}{c}\text { Plant } \\
\text { height } \\
\text { (cm }\end{array}$ & $\begin{array}{c}\text { Number } \\
\text { of small } \\
\text { tubers } \\
\text { plant-1 } \\
(<25 \text { gm })\end{array}$ & $\begin{array}{c}\text { Number } \\
\text { of } \\
\text { medium } \\
\text { tubers } \\
\text { plant-1 } \\
(25-75 \\
\text { gm) }\end{array}$ & $\begin{array}{c}\text { Number } \\
\text { of large } \\
\text { tubers } \\
\text { plant-1 } \\
(>75 \\
\text { gm) }\end{array}$ & $\begin{array}{c}\text { Tuber } \\
\text { weight } \\
\text { plant- } \\
1(\mathrm{~g})\end{array}$ & $\begin{array}{l}\text { Surviva } \\
\quad 1 \\
\text { percent } \\
\text { age }(\%)\end{array}$ & $\begin{array}{l}\text { Yield } \\
\text { (tons } \\
\text { ha-1) }\end{array}$ \\
\hline $\mathbf{O}$ & $39.91 d$ & $2.11 \mathrm{~d}$ & $1.22 \mathrm{~d}$ & $1.78 \mathrm{~d}$ & $\begin{array}{c}381.72 \\
\mathrm{~d}\end{array}$ & $73.31 \mathrm{~d}$ & $17.22 \mathrm{~d}$ \\
\hline 50 & $42.31 \mathrm{c}$ & $2.89 \mathrm{c}$ & $2.11 \mathrm{c}$ & $2.67 \mathrm{c}$ & $424.48 \mathrm{c}$ & $79.62 \mathrm{c}$ & $18.76 \mathrm{c}$ \\
\hline 75 & $45.82 \mathrm{a}$ & $4.56 \mathrm{a}$ & $4.11 \mathrm{a}$ & $4.56 \mathrm{a}$ & $463.67 \mathrm{a}$ & $89.56 \mathrm{a}$ & $21.65 \mathrm{a}$ \\
\hline 100 & $44.42 b$ & $3.67 \mathrm{~b}$ & $3.00 \mathrm{~b}$ & $3.44 \mathrm{~b}$ & $\begin{array}{c}454.17 \\
\mathrm{~b}\end{array}$ & $84.87 \mathrm{~b}$ & $20.59 b$ \\
\hline LSD at $\alpha 0.05$ & 1.133 & 0.711 & 0.853 & 0.736 & 4.123 & 4.129 & 0.861 \\
\hline
\end{tabular}

Means followed by the same Letter (s) do not differ significantly from one another at $5 \%$ probability level, using LSD test. 
Table 4. Plant height, bulb diameter, bulb weight, number of bulbs per kg and total yield of onion cultivars as affected by onion cultivars

\begin{tabular}{|c|c|c|c|c|c|c|c|}
\hline $\begin{array}{c}\text { Potato } \\
\text { Cultivars }\end{array}$ & $\begin{array}{c}\text { Plant } \\
\text { height } \\
(\mathbf{c m}\end{array}$ & $\begin{array}{c}\text { Number of } \\
\text { small } \\
\text { tubers } \\
\text { plant-1 } \\
(<\mathbf{2 5} \mathbf{g m})\end{array}$ & $\begin{array}{c}\text { Number } \\
\text { of } \\
\text { medium } \\
\text { tubers } \\
\text { plant-1 } \\
\mathbf{( 2 5 - 7 5} \\
\text { gm) }\end{array}$ & $\begin{array}{c}\text { Number } \\
\text { of large } \\
\text { tubers } \\
\text { plant-1 } \\
(\mathbf{> 7 5} \mathbf{g m})\end{array}$ & $\begin{array}{c}\text { Tuber } \\
\text { weight } \\
\text { plant- } \\
\mathbf{1}(\mathbf{g})\end{array}$ & $\begin{array}{c}\text { Survival } \\
\text { percentage } \\
(\mathbf{\%})\end{array}$ & $\begin{array}{c}\text { Yield } \\
\text { (tons ha- } \\
\mathbf{1})\end{array}$ \\
\hline Rocko & $43.06 \mathrm{~b}$ & $3.25 \mathrm{~b}$ & $2.42 \mathrm{~b}$ & $2.92 \mathrm{~b}$ & $432.97 \mathrm{~b}$ & $81.25 \mathrm{~b}$ & $19.64 \mathrm{~b}$ \\
\hline Kuroda & $45.33 \mathrm{a}$ & $3.92 \mathrm{a}$ & $3.33 \mathrm{a}$ & $3.83 \mathrm{a}$ & $451.17 \mathrm{a}$ & $85.30 \mathrm{a}$ & $21.15 \mathrm{a}$ \\
\hline Asterix & $40.97 \mathrm{c}$ & $2.75 \mathrm{~b}$ & $2.08 \mathrm{~b}$ & $2.58 \mathrm{~b}$ & $408.44 \mathrm{c}$ & $78.98 \mathrm{~b}$ & $17.88 \mathrm{c}$ \\
\hline $\begin{array}{c}\text { LSD at } \boldsymbol{\alpha} \\
\mathbf{0 . 0 5}\end{array}$ & 1.299 & 0.586 & 0.500 & 0.661 & 5.578 & 3.818 & 0.600 \\
\hline
\end{tabular}

Means followed by the same Letter (s) do not differ significantly from one another at $5 \%$ probability level, using LSD test

Number of small tuber plant $^{-1}(<25$ gm)

Number of small tuber plant $^{-1}$ was significantly affected by supplemental potassium levels and potato cultivars (Table 3).Mean table data showed that the maximum number of small tubers plant $^{-1}(4.56)$ was found in supplemental potassium applied at the rate of $75 \mathrm{~kg} \mathrm{ha}^{-1}$, followed by (3.67) at $100 \mathrm{~kg} \mathrm{ha}{ }^{-1}$ of supplemental potassium. Lowest number of small tubers plant ${ }^{-1}(2.11)$ was found in control plots. Similarly among cultivars, the higher number of small tubers plant $^{-1}$ (3.92) was found in cultivar Kuroda and lowest number of tubers plant ${ }^{-1}(2.75)$ was found in cultivar Asterix. It is clearly mention in the above results that potassium application upto certain limits increase the number of tubers this is because of positive effect of potassium application on plant height, stems per plant, leaf area and other plant growth variables which ultimately result in increased number of tubers. Tuber number was decreased at the highest rate of supplemental potassium application (100 kg $\mathrm{ha}^{-1}$ ) because of its adverse effect, when applied in excessive amount. [21] Backed our findings by revealing that potassium have negative effect on plant growth and yield because of its antagonistic effect on other nutrients if applied above optimum level. The increase in number of tubers also varies among different cultivars depending on the nature, structural and physiological characteristics of the cultivars because of their different genetic makeup. Same result was reported by [24], who concluded that potato cultivars showed different response to NPK levels.

Number of medium tuber plant $^{-1}(45-75$ gm)

Statistical study showed that the supplemental potassium levels and potato cultivars has significantly affected the number of medium tuber plant $^{-1}$ (Table 3).Mean table indicated that maximum number of medium tuber plant ${ }^{-1}$ (4.11) was observed in supplemental potassium applied at the rate of $75 \mathrm{~kg} \mathrm{ha}^{-1}$, followed by (3.0) number of medium tuber plant ${ }^{-1}$ at $100 \mathrm{~kg} \mathrm{ha}^{-}$ ${ }^{1}$ of supplemental $\mathrm{K}$, while the minimum number of medium tuber plant ${ }^{-1}$ (1.22) was recorded at check plots. In case of cultivars, the utmost number of medium tuber plant ${ }^{-1}$ (3.33) was found in cultivar Kuroda, pursued by cultivar Rocko with (2.42) number of medium tuber plant $^{-1}$ and the minimum number of medium tuber plant ${ }^{-1}(2.08)$ was found in cultivar Asterix. Potassium application helps in activation of certain enzymes required for photosynthesis 
processes, synthesis of proteins and metabolism of carbohydrates and also helps in transformation of carbohydrates from source to sink. Our finding was supported by [25], they reported that potassium application increase the number and size of medium and large tubers of potato. These results are also in collaboration with [26], who revealed that number of tubers vary with application of different levels of potassium. Result showed that number of medium tubers was also significantly different among potato cultivars. These results are in agreement with [27], who reported that the potato varieties respond different to applied potassium because of their different genetic makeup and yield potential and it also depends on ecological conditions.

\section{Number of large tuber plant $^{-1}(>75$ gm).}

Statistical analysis shows that the number of large tuber plant ${ }^{-1}$ is significantly influenced by supplemental potassium levels and potato cultivars, while the combine effect for $\mathrm{K}$ and potato cultivars was non-significant(Table 4). The maximum number of large tuber plant ${ }^{-}$ ${ }^{1}$ (4.56) was found at supplemental potassium applied at the rate of $75 \mathrm{~kg} \mathrm{ha}^{-1}$, followed by (3.44) number of large tuber plant $^{-1}$ at $100 \mathrm{~kg}$ ha $^{-1}$ of supplemental $\mathrm{K}$ and lowest number of large tuber plant ${ }^{-1}(1.78)$ was found in control plots. Similarly the most number of large tuber plant ${ }^{-1}$ (3.83) was observed in cultivar Kuroda, followed by (2.92) number of large tuber plant ${ }^{-1}$ for cultivar Rocko and the minimum number of large tuber plant ${ }^{-1}$ (2.58) was observed in cultivar Asterix. Potassium increase the plant height when applied at optimum amount, so more plant height produce strong root system which support increase amount of tubers resulting in increased yield. Our findings are in agreement with [25] and [28], who revealed that potassium, increase the nutrient uptake, assimilate flow, increase photosynthesis so more amount of protein and sugar was produced and as a result increased number and size of tuber was obtained. [29], also reported that the potato nutrient uptake ratio is quite high as compare to other crops because due to faster growth rate and tuber bulking. The rapid and increase bulking of potato is producing large size of tuber in response to potassium application. Results showed the number of large tubers was significantly different among potato cultivars, which are in collaboration with [27], who reported that the response of potato varieties to applied potassium level, depends on its genetic makeup, yield potential and also depend on ecological conditions.

\section{Tuber weight plant $^{-1}$ (gm)}

Supplemental potassium (K) levels and potato cultivars significantly influenced tuber weight plant $^{-1}$ (Table 3).Maximum tuber weight plant $^{-1}$ (463.67) was found at supplemental Potassium applied @ of 75 kg ha $^{-1}$, followed by (454.17) tuber weight plant ${ }^{-}$ ${ }^{1}$ at $100 \mathrm{~kg} \mathrm{ha}^{-1}$ of supplemental $\mathrm{K}$, and the minimum tuber weight plant $^{-1}$ (381.72) was found in check plots. In case of cultivars, the maximum tuber weight plant $^{-1}$ (451.17) was found in cultivar Kuroda, followed by (432.97) tuber weight plant $^{-1}$ in cultivar Rocko, and the minimum tuber weight plant $^{-}$ ${ }^{1}$ (408.44) was found in cultivar Asterix. It is evident that tuber weight is related with number of tubers and size of the tubers, so increased number of tubers will have high tuber weight. Leaves are the primary source where assimilates are formed and then transported to sink, plant with more leaf area and number of leaves will have generally more tuber weight and ultimately the yield will be high. These results are similar with [30] who revealed that the potato tuber weight increased with optimum level of $\mathrm{K}$ applied, while the yield was decreased with the excessive application of potassium that might be due to the adverse effect of excessive dose of potassium on growth and yield. Similar result was also reported by [31], who reported that excessive application 
of potassium decrease the yield. Potassium uptake efficiency also vary among different cultivars of potato, this may be because of their different genetic makeup. Our result was also supported by [28], who reported that response to the potassium fertilization is significantly influenced by the potato cultivars grown.

\section{Survival percentage}

Supplemental potassium (K) levels and potato cultivars have significant effect on survival percentage (Table 4).In case of supplemental potassium levels, the maximum (89.56) survival percentage was recorded in plots treated with supplemental potassium at rate of $75 \mathrm{~kg} \mathrm{ha}^{-1}$, chased by $(84.87 \%)$ at 100 $\mathrm{kg} \mathrm{ha}^{-1}$ of supplemental $\mathrm{K}$ and the minimum (73.31) percent survival was found in control plots. Similarly the maximum survival percentage (85.30) was found in cultivar Kuroda, followed by (81.25) in cultivar Rocko and the minimum percent survival (78.98) was found in cultivar Asterix. Plant exposed to different environmental stresses like drought, frost damage, and nutrient limitations, cause oxidative damage by producing reactive oxygen species [31] which ultimately decrease plant growth and yield by decreasing photosynthesis and assimilate transport. [32].

Supported our findings by reporting that potassium plays a vital role by providing resistance against different abiotic and biotic stresses by increasing phospholipids, permeability and improvement in bio physical and biochemical properties of cell. Our results are also in agreement with [14], who reported that potassium application reduces biotic stresses, resistance to low moister availability by stomata regulation and cell membrane stability, resistance increase salt tolerance, frost resistance. Potato cultivar shows differences in growth and yield that might be because of their genetic makeup. [22, 33] also supported our finding by reporting that potassium uptake efficiency and $\mathrm{K}$ utilization is significantly different among different genotypes of potato because of the different genetic makeup. They also concluded that superlative yield was achieved at potassium applied at the rate of $300 \mathrm{~kg} \mathrm{ha}^{-1}$.

\section{Yield (tons ha-1)}

The data showed that supplemental potassium levels and potato cultivars had significant effect on the yield (tons $\mathrm{ha}^{-1}$ ), while there interaction was non-significant (Table 3).Supplemental potassium applied at the rate of $75 \mathrm{~kg} \mathrm{ha}^{-1}$ showed highest yield (21.65 tons ha-1), followed by (20.59 tons ha$\left.{ }^{1}\right)$ at $100 \mathrm{~kg} \mathrm{ha}^{-1}$ of supplemental potassium and the minimum yield (17.22 tons ha-1) was recorded in check plots. The maximum yield (21.15 tons $\mathrm{ha}^{-1}$ ) was found in cultivar Kuroda, followed by cultivar Rocko with the yield of (19.64 tons $\left.\mathrm{ha}^{-1}\right)$ and the minimum yield (17.88 tons $\mathrm{ha}^{-1}$ ) was found in cultivar Asterix. Potassium application increase plant growth and yield because of increasing the plant height, plant vigor, increase leaf area, delay leaf shedding and produce resistance to biotic and abiotic stresses. It also increase assimilate flow from source to sink, activation of different enzymes involve in photosynthesis and rate and duration of tuber bulking [26]. Increase in tubers number and tuber weight is directly related with yield of the crop. More tuber weight and tuber number more will be the yield. As potassium produce resistance to different abiotic and biotic stresses so an ideal environment was provided for crop growth so a result increase yield was obtained. These results corroborate with the results of [30 who evaluated that highest yield was obtained with optimum $\mathrm{K}$ nutrition, while excessive level of $\mathrm{K}$ decreased the yield significantly. All the cultivar showed significant differences in yield (ton $\mathrm{ha}^{-1}$ ), these results are in agreements of [23] who reported that potato varieties show variation among different attributes like leaf area, plant height, 
nutrients uptake, yield potential and response to agro-climatic conditions, these might be because of their genetic factors.

\section{Conclusion and recommendations}

It is concluded from the experiment that supplemental potassium application has significant effect on growth and yield of potato cultivars. Supplemental potassium application at the rate of $75 \% \mathrm{~kg} \mathrm{ha}^{-1}$ show highest effect on the growth, yield and tuber quality of potato cultivars while the lowest result was found in control plots. Among all cultivars the cultivar Kuroda shows the maximum response to the supplemental potassium application while the cultivar Asterix showed the minimum response to the applied potassium levels. The interaction between supplemental potassium levels and potato cultivars was found non-significant.

In the light of above conclusions, following recommendation are made.

According to the research Supplemental potassium should be applied at the rate of 75 $\mathrm{kg} \mathrm{ha}^{-1}$ for the better growth, yield and tuber quality of potato cultivars. Cultivar Kuroda showed highest response to the applied supplemental potassium levels and is recommended for the good crop yield and quality under the agro-climatic region of Peshawar. Further research is required on supplemental potassium application and suitable cultivars for superior crop yield and quality under different cropping pattern for the region of Khyber Pakhtunkhwa.

\section{Authors' contributions}

Conceived and designed the experiments: $S$ farooq \& $G$ Ayub, Performed the experiments: MW Khan, Analyzed the data: R Riaz, K Rauf \& M Afzal, Contributed materials/ analysis/ tools: R Ullah, I Khan \& SQA Shah, Wrote the paper: A Naeem \& M Ali.

\section{References}

1. Malik MN (1994). Horticulture, Vegetable crops, National Book foundation, Islamabad, pp 490.
2. Amador V, Bou J, Martinez J \& Monte E (2003). Regulation of potato tuberization by day length and gibberellins. Intler $J$ Deve Bio (45): 37-38.

3. Spooner DM \& Bamberg JB (1994). Potato genetic resources of resistance and systematics. Amer Potato J 71: 325-338.

4. Aslam M \& Amin S (2014). Fruits, vegetables and condiment statistics of Pakistan 2012-2013. Printing copr. Pak. Press Islambad, pp 17-88.

5. Adbel-Aal ZS, Khalf-Alia A, Al-Shal M \&Qader MA (1977). Vegetable Production. Al-Jadida Publisher Alexandria, pp 15-57.

6. Tindall HD (1968). Commercial vegetable growing. The English language book society and Oxford Univ. Press, pp 210.

7. Patricia I \& Bansal SK (1999). Integrated nutrient management in potato. Abs. Global Conf. on Potato. New Delhi, Dec. 6-11, pp105.

8. Pushkarnath A \& Sardana MG (1965). Economics of $\mathrm{K}$ fertilization of potato. Indian potato J7: 3-8.

9. Askegaard M, Eriksen J \& Johnston AE (2004). Sustainable management of potassium, pp 85-102.

10. Bergmann W (1992). Nutritional disorders of plants-development, Visual and Diagnosis, Gustav Fischer, Jena Veriag, NY, pp 371-372.

11. Akhtar ME, Saleem MT \& Stauffer MD (2003). Potassium in Pakistan agriculture. In: Proc. XII Int. forum on soil taxonomy and agro-technology transfer. Soil Surv Pak, Islamabad.

12. Brady NC \& Weil RR (2002). The Nature and properties of soil, 13th edition, Prentice Hall, New Jersey.

13. Umar S Moinuddin H (2002). Effect of sources and rates of potassium application on potato yield and economic returns. Better Crops Inter15: 13-15.

14. Wang M, Zheng Q, Shen Q \&Guo S (2013). The critical role of potassium in plant stress response. Inter J Moleculer Sci 14: 7371.

15. Ulrich A \& Ohki K (1996). Potassium, In: Diagnostic criteria for plants and soils. 
University of California Press, Berkeley, pp 362-393.

16. Hijmans R J (2003). The effect of climate change on global potato production. Amer $J$ of Potato Res 80: 271-280.

17. Steel RGD \&Torrie JH (1980). Analysis of covariance, In: Principles and Procedures of Statistics: a Biometrical Approach, SMC Graw-Hill, New York, pp 401-437.

18. Khandakhar SMAT, Rahman MM, Uddin MJ, Khan SAKU \& Quddus KG (2004). Effect of lime and potassium on potato yield in acid soil. Pak J Bio Sci 7(3): 380-383.

19. Shehata SA \& Abo-Sedera (1994). Effect of irrigation frequency and NPK level on growth, yield, chemical composition and storage ability of potato. Zagazig J Agric Res 21: 129-149.

20. Berisha D, Susaj E, Bardhi N, Susaj L \&Havolli V (2014). Effect of Potassium rate on several vegetatitve and yield characters of potato, grown under two different agroclimatic regions of Kosovo. Inter Interdis $\operatorname{Res} J(6)$ : 62-69.

21. Malvi U (2011). Interaction of micronutrients with major nutrients with special reference to potassium. Kar J Agric Sci 24(1): 106-109.

22. George MS, Lu G \& Zhou W (2002). Genotypic variation for potassium uptake and utilization efficiency in sweet potato. Field Crop Res 77: 7-15.

23. Uwah DF, Undie UL, John NM \&koha U (2013). Growth and yield response of improved sweet potato varieties to different rates of potassium fertilizer in Calabar, Nigeria. J Agri Sci 5(7): 61-69.

24. Trehan, SP \& Grewal JS (1990). Effect of time and level of potassium application on tuber yield and potassium composition of plant tissue and tubers of two cultivars. Indian Agri. Res. Inst., New Delhi.

25. Bansal SK \&Trehan SP (2011). Effect of potassium on yield and processing quality attributes of potato. Kar J Agric Sci 24(1): 48-54.

26. Imas P \& Bansal SK (1999). Integrated nutrition management in potato. Proc. Symp. Global Potato Meet, Central Plant. Res. Inst., New Delhi. Research in Plants, held at Louvain-la-Neuve, Belgium, 19-21 June 1989. International Potash Institute, Bern, Switzerland, pp 219- 248.

27. Trehan SP (2007). Efficiency of potassium utilization from soil as influenced by different potato cultivars in the absence and presence of green manure (Sesbaniaaculeata). Advances Hort Sci 21(3): 156-164.

28. Trehan SP, Roy SK \& Sharma RC (2001). Potato variety Differences in nutrient deficiency symptoms and responses to NPK. Better crops Inter 15: 18-21.

29. Singh JP, Trehan SP \& Sharma RC (1997). Crop residue management for sustaining the soil fertility and productivity of potato based cropping systems in Punjab. J Indian Potato Assoc 24: 85-99.

30. Pervez MA, Choudhary MA, Shaheen MR \& Noor MA (2013). Determination of physio morphological characteristics of potato crop regulated by potassium management. Pak J Agric Sci 50(4): 611615.

31. Cakmak I (2005). The role of potassium in alleviating detrimental effects of abiotic stresses in plants. J Plant Nutrn. Soil Sci (168): 521-530.

32. Hakerlerler H, Oktay M, Eryuce N \&Yagmur B (1997). Effect of potassium sources on the chilling tolerance of some vegetable seedlings grown in hotbeds. In food security in the Wana region, the essential need for balanced fertilization, Johnston, A.E., Int. Potash Inst., Basel, Switzerland, pp 353-359.

33. Jasim AH (2013). Effect of foliar fertilizer on growth and yield of seven potato cultivars. Sci. Papers. Series B, Horticulture. 7: 77-80. 